\title{
Urban energy budget models
}

Book or Report Section

Accepted Version

Grimmond, C. S. B., Jarvi, L., Lindberg, F., Marras, S., Falk, M., Loridan, T., Pigeon, G., Pyles, D. R. and Spano, D. (2014) Urban energy budget models. In: Chrysoulakis, N., de Castro, E. A. and Moors, E. J. (eds.) Understanding Urban Metabolism. Routledge, pp. 91-105. ISBN 9780415835114 Available at https://centaur.reading.ac.uk/52740/

It is advisable to refer to the publisher's version if you intend to cite from the work. See Guidance on citing.

Publisher: Routledge

All outputs in CentAUR are protected by Intellectual Property Rights law, including copyright law. Copyright and IPR is retained by the creators or other copyright holders. Terms and conditions for use of this material are defined in the End User Agreement.

\section{www.reading.ac.uk/centaur}

\section{CentAUR}

Central Archive at the University of Reading

Reading's research outputs online 


\section{URBAN ENERGY BUDGET MODELS}

\section{CSB Grimmond ${ }^{1,2}$, Leena Järvi ${ }^{3,2}$, Fredrik Lindberg ${ }^{4,2}$, Serena Marras ${ }^{5,9}$, Matthias Falk ${ }^{6,9}$,} Thomas Loridan ${ }^{7,2}$, Gregoire Pigeon ${ }^{8}$, David R. Pyles ${ }^{6,9}$, Donatella Spano ${ }^{5,9}$

${ }^{1}$ Department of Meteorology, University of Reading, Reading UK RG6 6BB, UK, T: +44 118 3786248, C.S.Grimmond@ reading.ac.uk ${ }^{2}$ King's College London, London, UK ${ }^{3}$ University of Helsinki, Department of Physics, PL 48, FIN-00014, Helsinki, Finland, tel. +358503110371 , email: leena.jarvi@helsinki.fi ${ }^{4}$ University of Göteborg, Gothenburg, Sweden, tel.: +46 31 7862606, e-mail: fredrikl@gvc.gu.se ${ }^{5}$ University of Sassari, Via Enrico De Nicola 9, 07100 Sassari, Italy, tel.: +39079 229339, e-mail: spano@ uniss.it ${ }^{6}$ University of California, Davis, USA ${ }^{7}$ RMS, London, $U K^{8}$ Meteo France, Toulouse, France ${ }^{9}$ Euro-Mediterranean Center on Climate Change (CMCC), Italy

\section{INTRODUCTION}

As part of the BRIDGE project (Chrysoulakis et al. 2013), the urban energy balance (UEB) fluxes (Chapter 4) were measured (Chapter 5) and modelled, independently and nested in meso-scale models (Chapter 7). In this chapter we consider the models used and their performance. Knowing how well models perform is critical if they are to be used to evaluate impacts of proposed changes in an urban area (Chapter 17), such as adding trees, and their impacts on the surface energy, water (Chapter 10), and carbon (Chapter 11) exchanges and air quality (Chapter 8).

A large number of models now exist that are able simulate urban surface-atmosphere exchanges (for a recent review see Grimmond et al. 2009). No single 'perfect' urban land surface model exists (Grimmond et al. 2010, 2011), hence a powerful methodology is to use a range of models (an ensemble approach) to consider probable impacts of changes to the urban surface on atmospheric conditions.

Here we consider five different models (section "Models used in BRIDGE"), run by different research groups using slightly different set-ups for each of the case study cities (section "Application and Results"). First, we describe the models and then assess their performance.

\section{MODELS USED IN BRIDGE}

The five urban land surface models used to investigate urban energy balance fluxes in the five BRIDGE cities studied in BRIDGE (Firenze, Helsinki, London, Gliwice, Athens):

(1) Advanced Canopy-Atmosphere-Soil Algorithm (ACASA)

(2) Noah land surface model and the Single Layer Urban Canopy Model (Noah/SLUCM)

(3) Surface Urban Energy and Water Balance Scheme (SUEWS)

(4) Local scale Urban Parameterization Scheme (LUMPS )

(5) Town Energy Balance (TEB)

In addition, for anthropogenic heat flux the Large scale Urban Consumption of energY model (LUCY) was used.

All of the models are fully described in papers in the refereed literature (referred to in the following subsections); hence most details are not repeated here. Some of the models have been extensively evaluated (e.g. TEB), whereas others which are relatively new (e.g. ACASA) have not been.

\section{ACASA}

The Advanced Canopy-Atmosphere-Soil Algorithm (ACASA) (Pyles et al. 2003), developed by University of California - Davis, is a multilayer model that extends to $100 \mathrm{~m}$ above the canopy elements to ensure applicability of the turbulence assumptions. The canopy height considered is assumed to be the maximum eddy covariance (EC) tower height. In its current configuration, buildings and vegetation are assumed to be the same height. The model uses mass conservation with the absorbed available energy partitioned into sensible and latent heat flux densities. Energy balance closure is not forced, and the available energy partitioning is calculated using the Bowen ratio to ensure conservation of energy.

ACASA uses higher-order closure equations to estimate turbulent fluxes and profiles (Meyers and Paw U 1986, 1987) and to predict effects that higher-order turbulent kinetic and thermodynamic processes have on the surface microenvironment and associated fluxes of heat, moisture and momentum. These processes include turbulent production and dissipation to turbulence kinetic energy, turbulent vertical transport of heat, mass and momentum fluxes.

To estimate radiation, multiple surface element angle classes (nine sunlit and one shaded) and direct as well as diffuse radiation absorption, reflection, transmission and emission, are considered to estimate energy fluxes per each layer. For each angle class, the flux sources and sinks are estimated per each canopy element type (leaf, stem, building wall) and surface state (dry, wet, ice/snow-covered). Built surfaces and stems are assumed always to be dry.

Three types of surfaces are included into the model (building materials, vegetation, and soil); their characteristics have to be specified to run the model. Building properties such as the values of thermal conductivity and emissivity, heat capacity of building material and the internal building temperature are adjustable, to allow different scenarios to be considered with different building materials and features (i.e., changing roof albedo, introducing vegetated facades, etc.). Urban fluxes are calculated as proportional to population density: the more people there are in an area, the more built surfaces are assumed to be influencing the flux sources and sinks. 
Grimmond CSB, L Järvi, F Lindberg, S Marras, M Falk, T Loridan, G Pigeon, DR Pyles, D Spano 2015: Urban Energy Budget Models (Chap. 9) in Understanding Urban Metabolism ed N Chrysoulakis, E Castro, E Moors, Routledge, 91-105

http://www.routledge.com/books/details/9780415835114/ ISBN 978-0-415-83511-4

As input the model requires meteorological information (air temperature, wind speed, specific or relative humidity, precipitation, and air pressure), down-welling short and long wave radiation and carbon dioxide $\left(\mathrm{CO}_{2}\right)$ concentration. Inputs can be derived from surface measurements, or by mesoscale meteorological models, as well as morphological parameters to describe the surface. ACASA has been coupled to the mesoscale model WRF (Weather Research and Forecasting Model) to be surface-layer scheme beneath the lowest sigma-layer. When used with WRF, the Mellor-Yamada-Janjic (Janjic 1994) Planetary Boundary Layer (PBL) scheme was with the ACASA determined Turbulence Kinetic Energy (TKE) to calculate the PBL development. In the BRIDGE project, ACASA was run for the Firenze and Helsinki case studies (Marras et al. 2012).

\section{SLUCM}

One of the urban land surface schemes in the Weather Research and Forecasting (WRF) meso-scale model, couples the Noah land surface model (Chen \& Dudhia 2001) and the Single Layer Urban Canopy Model (Kusaka et al. 2001, Kusaka \& Kimura 2004) through a tile approach. No interaction occurs between the two components, and the resulting outputs/fluxes are areally weighted as a function of the land cover fractions within each grid area. The model has been tested for numerous cities (e.g. Loridan et al. 2010, Loridan \& Grimmond 2012), including London (Loridan et al. 2013).

The original model is described in detail by Kusaka et al. (2001) and Kusaka \& Kimura (2004). For the vegetated part of the urban surface, the Chen \& Dudhia (2001) Noah scheme is used. Loridan et al. (2010) modified SLUCM to improve its performance; see the discussion by Chen et al. (2011) which puts these changes in the context of other urban components. Evaluation of the model includes participation in the Urban land surface model comparison (Grimmond et al. 2010, 2011) by more than one group.

The model generally does not simulate sensible heat flux well. This is thought to be because of the lack of interaction between the surface tiles, which means that the excess turbulent sensible heat flux cannot be dissipated via evaporation (Loridan et al. 2010, Loridan and Grimmond 2012). Also, the model appears to have been originally optimised for radiation (Loridan \& Grimmond 2012). Therefore changing coefficient values for the different parameters needs to be undertaken with caution when using the model for different scenarios, as in some cases it may result in the incorrect behaviour of the model.

\section{SUEWS and LUMPS}

The Surface Urban Energy and Water Balance Scheme (SUEWS) allows both the energy and water balances at the neighbourhood scale to be calculated. The model combines the urban evaporation-interception scheme of Grimmond \& Oke (1991) with the urban water balance model of Grimmond et al. (1986). Recent developments (Järvi et al. 2011) explicitly aim to reduce the number of required input variables and to include more fully the energy and water exchange processes. In SUEWS particular attention is given to the surface conductances (or the inverse - resistances) with a Jarvis (1976) approach used in the PenmanMonteith equation (Penman 1948, Monteith 1965). Järvi et al. (2011) provide general coefficients for urban environments. The model has surface and subsurface soil moisture stores. The above ground surfaces include paved areas, roofs, evergreen trees and shrubs, deciduous trees and shrubs, grass, and water. The vegetation can be irrigated and/or unirrigated. When the soil is saturated excess water becomes surface runoff and/or leaves the bottom of the modelled soil layer, as deep soil runoff.

The model is forced with commonly measured meteorological variables (wind speed, relative humidity, air temperature, pressure, precipitation, shortwave irradiance). Surface characteristics are required for each model grid area, including the plan area fraction of each surface type, number of inhabitants, fraction of irrigated area using automatic sprinklers; and internal hydrological connectivity (for example, based on elevation differences or pervious/impervious linkages or by piped network connectivity). The model undertakes calculations with a 5 min to hourly time step. The results are then aggregated to daily, monthly and annual time periods. Thus, SUEWS can simulate or be applied to periods of (less than) a day to multiple years. For each time period, surface characteristics and meteorological forcing can change or not as appropriate for the simulation. Other recent developments include addition of snow to the model so that it can more correctly simulate cold climate characteristics (Järvi et al. 2013). For a full description of the model see Järvi et al. (2011).

Within SUEWS, the simpler model LUMPS - the local scale urban parameterization scheme is included (Grimmond \& Oke 2002). Both SUEWS and LUMPS treat the radiation (Offerle et al. 2003, Loridan et al. 2011) and storage heat flux (Grimmond et al. 1991, Grimmond \& Oke 1999) in a common way. Evaluation of the full LUMPS modelled was conducted by Loridan et al. (2011) and of SUEWS by Järvi et al. (2011). Both models underwent additional development for the BRIDGE project. LUMPS participated in the international urban land surface model comparison, whereas SUEWS did not, as like ACASA, it was not ready.

\section{TEB}

The Town Energy Balance model (Masson 2000) simulates the energy and water exchanges between the city and the atmosphere. The most important processes that influence urban-atmosphere energy exchanges are taken into account in TEB, viz: radiative trapping and shadows resulting from the 3D geometry of a city; heat exchanges between the buildings and the environment; water interception and evaporation, and also changes in snow on roads and roofs (evaluated against Montreal data in Lemonsu et al. (2005)); drag, heat and water turbulent exchanges between the urban canopy layer and the atmosphere.

The 3D shape of a city is parameterized using an idealized 2D canyon geometry while keeping the main features driving the radiative interactions and energy exchanges. Likewise, energy balance computations are carried out by azimuthal averaging solar and wind forcing in order to represent neighbourhoods with random-oriented urban canyons. For impact studies, a version of the model with specific canyon orientations is also available (Lemonsu et al. 2013). The air flow within urban canyons is solved by applying aerodynamic resistances and, in the latest version, by applying an original 1D vertical turbulence scheme that simulates 
Grimmond CSB, L Järvi, F Lindberg, S Marras, M Falk, T Loridan, G Pigeon, DR Pyles, D Spano 2015: Urban Energy Budget Models (Chap. 9) in Understanding Urban Metabolism ed N Chrysoulakis, E Castro, E Moors, Routledge, 91-105

http://www.routledge.com/books/details/9780415835114/ ISBN 978-0-415-83511-4

the mean characteristics of the flow in the canyon, skipping unnecessary (and computationally expensive) details (Hamdi \& Masson 2008). Generally the parameterization is designed to allow fast computations.

The Building Energy Model (BEM) (Bueno et al. 2012) implemented in TEB considers a single thermal zone, a generic thermal mass to represent the thermal inertia of the indoor materials, the heat gains resulting from transmitted solar radiation and the internal sources of heat, infiltration and ventilation. The heat conduction through the envelope of the building is calculated using a finite difference method individually for each surface (roof, wall and floor). The morphological parameters of the TEB model are summarized in Table 9.1.

Table 9.1. TEB morphological parameters.

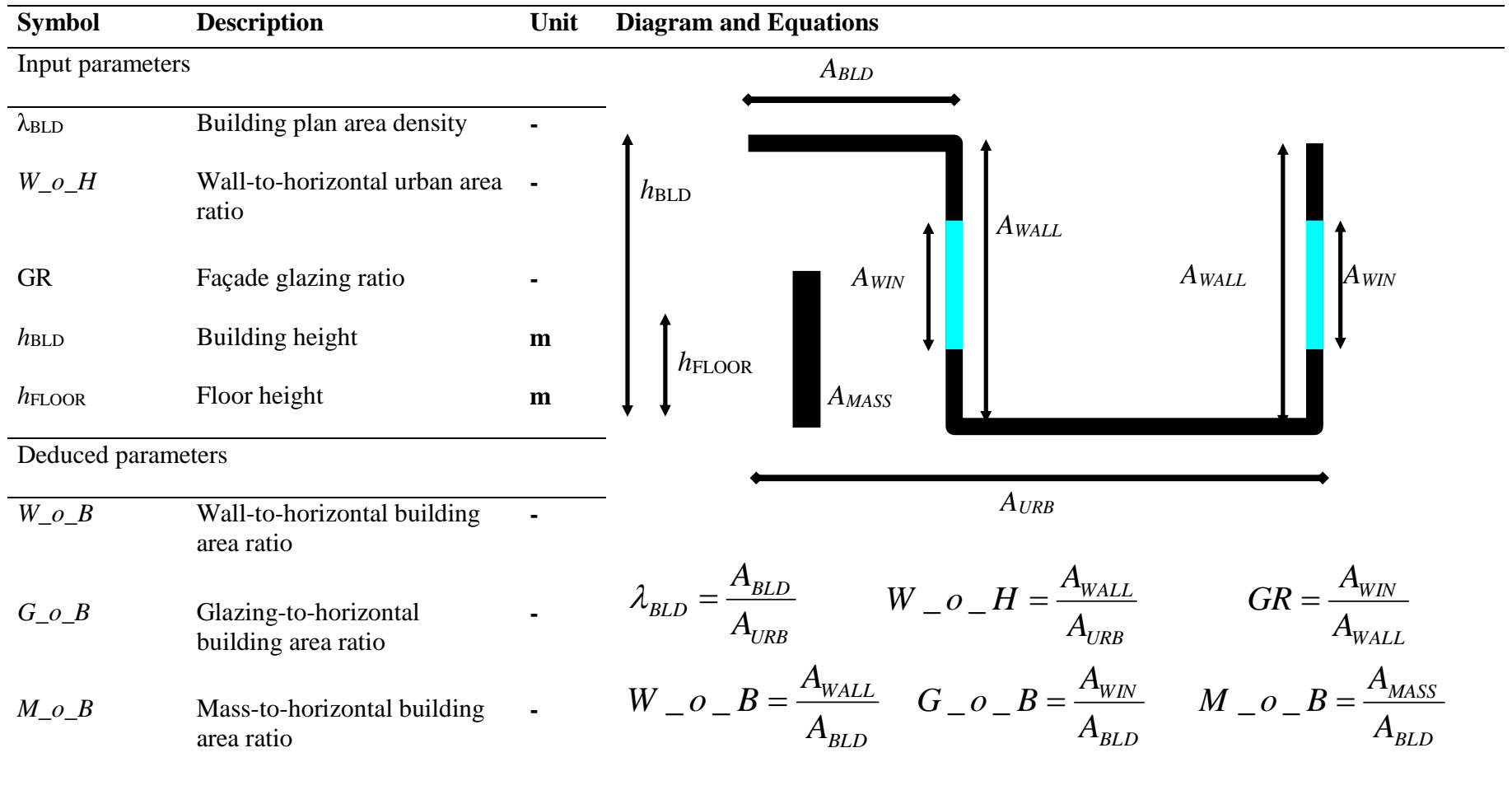

\section{LUCY}

The Large scale Urban Consumption of energY model (LUCY) allows the anthropogenic heat flux $\left(Q_{F}\right)$, and its spatial and temporal variability to be modelled (full details in Allen et al. 2011, Lindberg et al. 2013). The model includes the sensible heat released from transport or mobile sources, fixed or building sources and from people. LUCY calculates hourly fluxes and incorporates effects of the density of people across a city, monthly mean temperature, typical diurnal and day of week behaviour, details of the vehicle fleet and energy consumption for the country.

LUCY was run for all BRIDGE cities at the same spatial resolution using a consistent methodology. Here the model results are presented for one winter weekday (5 Feb 2008) and one summer weekday (16 July 2008) at 30 arc-second resolution (equivalent to $928 \mathrm{~m} \mathrm{x} 465 \mathrm{~m}$ in London). Only urban grid cells as classified by CIESIN (2004) are included in the analysis and monthly mean temperatures from the Willmott et al. (2011) dataset are used. Two areas of London are modelled: the greater London area (GLA) and the central activity zone (CAZ). The extents of each model domain and the population within them are shown in Table 9.2 .

\begin{tabular}{|c|c|c|c|c|c|c|}
\hline & London/GLA & Athens & Helsinki & Gliwice & Firenze & London/CAZ \\
\hline lat $_{\text {min }}$ & 51.29 & 37.83 & 60.14 & 50.26 & 43.74 & 51.48 \\
\hline lat $t_{\text {max }}$ & 51.70 & 38.13 & 60.30 & 50.33 & 43.81 & 51.54 \\
\hline $\operatorname{lon}_{\min }$ & -0.50 & 23.60 & 24.80 & 18.60 & 11.19 & -0.20 \\
\hline $\operatorname{lon}_{\max }$ & 0.30 & 23.80 & 25.10 & 18.74 & 11.31 & -0.07 \\
\hline pop $/ \mathrm{km}^{2}$ & 2922 & 4464 & 1700 & 1354 & 2770 & 8711 \\
\hline $\operatorname{area}\left(\mathrm{km}^{2}\right)$ & 2865 & 559 & 310 & 110 & 93 & 107 \\
\hline
\end{tabular}

Table 9.2. Modelled extents (lat, lon) used in LUCY and population density for each area.

\section{APPLICATION AND RESULTS}

The performances of the models are evaluated here based on observations collected in Helsinki, Firenze and London (see details of the observations in Chapter 5). The widest range of models were run in Helsinki. Direct comparison is possible for some of the models but not all. The anthropogenic heat flux model, LUCY, is the only model that is run for all five cities (Athens, Gliwice, Helsinki, Firenze and London).

\section{Helsinki}

In Helsinki five surface energy balance models (ACASA, LUMPS, SUEWS, and SLUCM) were compared with the eddy covariance observations undertaken at the SMEAR III (see Chapter 5) Kumpula site $\left(60^{\circ} 12^{\prime} \mathrm{N}, 2^{\circ} 57^{\prime}\right.$ E). The modelling groups ran their models for different periods. Here we consider the performance of four of the models for the period January to August 
Grimmond CSB, L Järvi, F Lindberg, S Marras, M Falk, T Loridan, G Pigeon, DR Pyles, D Spano 2015: Urban Energy Budget Models (Chap. 9) in Understanding Urban Metabolism ed N Chrysoulakis, E Castro, E Moors, Routledge, 91-105

http://www.routledge.com/books/details/9780415835114/ ISBN 978-0-415-83511-4

2008. The ACASA model was run with parameters indicated in Table 9.3 both offline (at the local-scale) and with WRF for a larger regional area. The SLUCM parameters and setup (see all details in Loridan and Grimmond 2012) used here are for Stage 4 all input parameters are optimized using the Multi Objective Shuffled Complex Evolution Metropolis (MOSCEM: Vrugt et al., 2003) algorithm. Thus this should be the best performance for this model.

\begin{tabular}{lccc}
\hline Parameter & Firenze & Helsinki & References \\
\hline Human population density $\left(\right.$ people $\left.\mathrm{m}^{-2}\right)$ & 0.0036 & 0.0027 & ISTAT, 2009; Pop.Res.Ctr.Finland, 2009 \\
Leaf Area Index $\left(\mathrm{m}^{2} \mathrm{~m}^{-2}\right)$ & 0.5 & 1.5 & This study \\
Canopy height $(\mathrm{m})$ & 36 & 31 & Matese et al., 2009; Järvi et al., 2009 \\
Interior building temperature $\left({ }^{\circ} \mathrm{C}\right)$ & 19 & 19 & ASHRAE, 1992 \\
Reflectivity (Visible) & 0.2 & 0.2 & Parker et al., 2000 \\
Reflectivity (Near Infrared) & 0.3 & 0.3 & Parker et al., 2000 \\
Thermal emissivity & 0.9 & 0.9 & Parker et al., 2000 \\
\hline
\end{tabular}

Table 9.3. Input parameters used in ACASA runs in Firenze and Helsinki

Figure 9.1 shows the mean monthly diurnal pattern of the observed and modelled net all-wave radiation, sensible and latent heat fluxes for ACASA, LUMPS, SLUCM and SUEWS. All four models are able to reproduce the diurnal behaviour of the fluxes well (Figure 9.1). The mean statistics for the models for each flux are presented in Table 9.4. For January ACASA overestimated the net all-wave radiation with mean biased error (MBE) of $12.7 \mathrm{~W} \mathrm{~m}^{-2}$ whereas for SUEWS MBE was $0.4 \mathrm{~W} \mathrm{~m}^{-2}$ and for LUMPS $1.0 \mathrm{~W} \mathrm{~m}^{-2}$.

Slight overestimation was simulated with SLUCM $\left(M B E=-4.1 \mathrm{~W} \mathrm{~m}^{-2}\right)$ Three models were able to capture the behaviour of the winter time $Q_{H}$ well (except SLUCM) and differences between the models were very small, both by day- and by night-time. $Q_{E}$ on the other hand was underestimated by SUEWS, LUMPS and SLUCM $\left(M B E=-12,-19.8\right.$ and $\left.-13.9 \mathrm{~W}^{-2}\right)$ and overestimated by $\operatorname{ACASA}\left(M B E=30.5 \mathrm{~W} \mathrm{~m}^{-2}\right)$.

\begin{tabular}{|c|c|c|c|c|c|c|c|}
\hline & & \multicolumn{2}{|c|}{$Q^{*}$} & \multicolumn{2}{|c|}{$Q_{H}$} & \multicolumn{2}{|c|}{$Q_{E}$} \\
\hline & & Mean & $N$ & Mean & $N$ & Mean & $N$ \\
\hline \multirow[t]{2}{*}{ Observed } & Jan & -20.9 & 720 & 17.6 & 187 & 23.2 & 58 \\
\hline & Aug & 69.4 & 738 & 37.3 & 341 & 63.0 & 311 \\
\hline Modelled & & RMSE & $M B E$ & RMSE & MBE & RMSE & $M B E$ \\
\hline \multirow{2}{*}{ ACASA } & Jan & 7.4 & 12.7 & 40.4 & -14.3 & 13.7 & 30.5 \\
\hline & Aug & 39.6 & 13.3 & 53.1 & 25.9 & 24.3 & -2.7 \\
\hline \multirow{2}{*}{ SUEWS } & Jan & 2.9 & 0.4 & 24.4 & -12.5 & 16.5 & -12.0 \\
\hline & Aug & 5.1 & -4.7 & 31.6 & -4.6 & 29.8 & -14.0 \\
\hline \multirow{2}{*}{ LUMPS } & Jan & 2.9 & 1.0 & 24.1 & -11.8 & 1.9 & -19.8 \\
\hline & Aug & 5.1 & -4.7 & 37.9 & 15.8 & 19.7 & -33.7 \\
\hline \multirow{2}{*}{ SLUCM } & Jan & 7.0 & -4.5 & 10.4 & -30.1 & 4.2 & $-13, .9$ \\
\hline & Aug & 41.9 & -22.5 & 29.1 & 15.8 & 17.1 & -32.9 \\
\hline
\end{tabular}

Table 9.4: Observed (mean) and model performance evaluation statistics (RMSE; $W m^{-2}$ and MBE, W $m^{-2}$ ) for four urban landsurface models. The model runs and observations are for Helsinki in January and August 2008. The number of 30 min data points that are used in the statistics are indicated by $N$.

Larger differences between the models were observed in August than in January. ACASA tends to overestimate $Q^{*}$ and $Q_{H}(M B E$

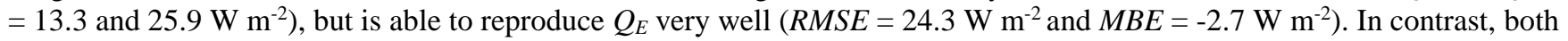
SUEWS and LUMPS underestimated $Q^{*}$ in the daytime, but were able to simulate nocturnal radiation levels correctly. SUEWS underestimated the daytime $\mathrm{Q}_{\mathrm{H}}$, but was able to predict the diurnal pattern in $Q_{E}$. LUMPS in contrast underestimated $Q_{E}$ but simulates $Q_{H}$ correctly. SLUCM underestimates $Q^{*}\left(M B E=-22.5 \mathrm{~W} \mathrm{~m}^{-2}\right)$ particularly at night-time, overestimates $Q_{H}(M B E=-$ $15.8 \mathrm{~W} \mathrm{~m}^{-2}$ ) and clearly underestimates $Q_{E}$, similar to LUMPS. The conclusions are similar to those obtained in the Urban PILIPs model comparison study (Grimmond et al. 2011); individual models have their strengths and weakness in modelling the different energy balance components.

When WRF - ACASA was used to calculate the fluxes for a $0.6 \mathrm{~km}$ by $0.6 \mathrm{~km}$ grid size inner domain (Falk et al. 2013), the instantaneous (30-min) fluxes derived were compared for the entire month of June 2008. The $Q_{H}$ and $Q_{E}$ fluxes have similar magnitude to the daily maxima, indicating the effects of significant vegetation in the flux footprint with a Bowen ratio $\left(\beta=Q_{H} /\right.$ $Q_{E}$ ) of roughly 1 . Generally, the model and observations had the same daily pattern. Typically the model errors were within the error range of the EC observations. The average peaks for both were $250 \mathrm{~W} \mathrm{~m}^{-2}$ for $Q_{H}$ and $200 \mathrm{~W} \mathrm{~m}^{-2}$ for $Q_{E}$. WRF-ACASA captured heterogeneous forcing related to land cover differences across the urban landscape (Figure 9.2). Differences between night-time and daytime fields also indicate robust simulation of the diurnal cycle for the different land use types.

\section{Firenze}

Energy and mass fluxes were simulated in the Firenze city centre with an uncoupled or in situ version of ACASA for two years (2008 and 2010) using a 30 minute time step. Meteorological data (air temperature, relative humidity, precipitation, and wind speed) collected at the Ximeniano Observatory $\left(43^{\circ} 47^{\prime} \mathrm{N}, 11^{\circ} 15^{\prime} \mathrm{E}\right.$ ) and a constant $\mathrm{CO}_{2}$ concentration value (388 ppm, annual mean Mauna Loa Observatory, Hawaii, 2009 -2010 (NOAA 2012) were used to force the model. The morphological parameters (Table 9.3) related to vegetation (i.e., Leaf Area Index LAI, maximum rate of Rubisco-mediated carboxylation $\mathrm{V}_{\mathrm{cmax}}$ ) are for broadleaf species that grow rapidly (large $\mathrm{V}_{\mathrm{cmax}}$, for instance) in urban areas. However, the city centre of Firenze has very little vegetation, so a small LAI value was set for this city (Table 9.3). Note the model does not use the percentage of vegetation surface cover, so to control the vegetation amount the LAI is changed. The soil type class corresponding to concrete surfaces was used for simulations. 
Grimmond CSB, L Järvi, F Lindberg, S Marras, M Falk, T Loridan, G Pigeon, DR Pyles, D Spano 2015: Urban Energy Budget Models (Chap. 9) in Understanding Urban Metabolism ed N Chrysoulakis, E Castro, E Moors, Routledge, 91-105

http://www.routledge.com/books/details/9780415835114/ISBN 978-0-415-83511-4

flux for Firenze on $15^{\text {th }}$ April 2008 (modified from Marras et al. 2012). These are modelled with WRF-ACASA at $200 \mathrm{~m} x 200 \mathrm{~m}$ resolution at the lowest WRF-sigma layer (approximately $50 \mathrm{~m}$ above the surface). (g) Land use map (WRF-ACASA) for Firenze, Italy. Dark grey colours indicate natural land cover, light grey colours urban land cover classes, white indicates water bodies (WRF 33 Land-use Classes, USGS33).

\section{London}

The SLUCM/Noah performance was evaluated both offline and within WRF (WRF-SLUCM/Noah for 3 June 2010 (Loridan et al. 2013), a period when a high pressure system was over the UK giving clear-sky conditions. Two sets of EC tower observations located at King's College London (KCL, $51.511^{\circ} \mathrm{N}, 0.116^{\circ} \mathrm{W}$ ) were used to evaluate the model performance (see Kotthaus and Grimmond 2012, 2013a,b and Loridan et al. 2013 for measurement details; also described in Chapter 5).

The SLUCM/Noah offline application uses local scale observations (incoming shortwave and longwave radiation, air temperature, relative humidity, wind components, and pressure) to force the model. When the scheme is linked to WRF-SLUCM/Noah (i.e. online) the forcing fields are simulated by WRF (see Loridan et al. (2013) for details of the modelling setup). For both offline and online runs the modelled fluxes are evaluated and the impact of the land-surface characterization assessed. For the online simulations the modelled meteorological variables can also be assessed. The spatial extent of the observed EC and radiation source area are smaller than the $1 \mathrm{~km}^{2}$ online grid cell used in WRF.

The diurnal evolution of the observed surface energy balance, the offline and online model fluxes are shown in Loridan et al.'s (2013) Figures 4 and 5. The model was run in Helsinki with a wide variety of land surface parameter values. These include the default parameter values for WRF V3.2.1 (termed 'stage 1'), with high values for the albedo (0.2) for the roof, road and wall. This results in a clear overestimation of reflected shortwave K $\uparrow$ (see Loridan et al.'s (2013) Figure 4a, RMSE $=25$ W $\mathrm{m}^{-2}$ and MBE of $12 \mathrm{~W} \mathrm{~m}^{-2}$, see their Table 4). At stage 5, when the parameter values are changed to the urban zone for energy partitioning (UZE) values recommended by Loridan \& Grimmond (2012), appropriate for the measurement site (in this case high density, HD), the model performance statistics are improved (Table 9.5). Similarly, the modelled daytime L $\uparrow$ is overestimated at stage 1, while stage 5 (UZE) yields results in better agreement with observations (RMSE reduced from $37 \mathrm{~W} \mathrm{~m}^{-2}$ to $11 \mathrm{~W}^{-2}$ Table 9.5). The daytime $\mathrm{Q}^{*}$ is underestimated at Stage $1\left(\mathrm{RMSE} \approx 59 \mathrm{~W} \mathrm{~m}^{-2}, \mathrm{MBE} \approx-43 \mathrm{~W} \mathrm{~m}^{-2}\right)$, but this bias is reduced by using UZE parameters $\left(\mathrm{RMSE} \approx 14 \mathrm{~W} \mathrm{~m}{ }^{-2}, \mathrm{MBE}=-6 \mathrm{~W} \mathrm{~m}^{-2}\right.$ ). However, for both (stage 1 and 5) peak daytime $\mathrm{Q}_{\mathrm{H}}$ is overestimated, whereas evening/early morning values are underestimated. With less $\mathrm{Q}^{*}$ at the surface, the Stage 1 parameters cause less daytime $\mathrm{Q}_{\mathrm{H}}$ release $\left(\mathrm{RMSE}=62 \mathrm{~W} \mathrm{~m}^{-2}\right)$. Although the underestimated $\mathrm{Q}_{\mathrm{E}}\left(\mathrm{MBE} \approx-19 \mathrm{~W} \mathrm{~m}^{-2}\right)$ is improved with UZE parameters $($ Table 9.5), the variability in the $\mathrm{Q}_{\mathrm{E}}$ observations means the statistics are not very robust.

Table 9.5: Performance of Noah/SLUCM in London on 3 June 2010 (data from Loridan et al. 2013 Stage $5 b$ ) compared to eddy covariance flux observations. Land surface parameters for model runs are UZE values.

\begin{tabular}{lcccc}
\hline & \multicolumn{2}{c}{ Offline } & \multicolumn{2}{c}{ Online } \\
$\mathrm{W} \mathrm{m}^{-2}$ & $R M S E$ & $M B E$ & $R M S E$ & $M B E$ \\
\hline$K \uparrow$ & 14 & -8 & 14 & -2 \\
$L \uparrow$ & 11 & 8 & 15 & 0 \\
$Q^{*}$ & 14 & 6 & 29 & -8 \\
$Q_{H}$ & 83 & 27 & 83 & 5 \\
$Q_{E}$ & 14 & -6 & 16 & -5 \\
\hline
\end{tabular}

\section{Anthropogenic heat flux in all five Cities - LUCY}

for the five cities (Figure 9.5). Results show that the central parts of London (CAZ) have the highest values of $\mathrm{Q}_{\mathrm{F}}$, both during winter and summer. The main reason for this is a high population density in combination with relatively high energy consumption which affects the heat released from buildings in the model. Examining the fluxes across the full extent of the London Greater London Authority, however, yields a mean $\mathrm{Q}_{\mathrm{F}}$ which is low because of lower population densities in the suburbs compared to the other cities examined. In winter, Helsinki has a relatively large release of $Q_{F}$ even though the population density is low (Table 9.2). This is because of the low winter temperatures which result in a high proportion of the yearly energy consumption used for heating during the cold winter months. In contrast, during summer $\mathrm{Q}_{\mathrm{F}}$ for Helsinki is the second lowest because little energy is needed to heat or cool buildings. Athens has $\mathrm{Q}_{\mathrm{F}}$ fluxes very close to those of the dense London CAZ in summer given the high proportion of the energy used to cool buildings during the hot summer. In contrast, cities in UK use very little energy to cool buildings during summer (see Figure 4 in Lindberg et al. 2013) and hence, energy released by buildings as well as the total $Q_{F}$ is much lower in summer compared to winter. $Q_{F}$ in Firenze is relatively low because the relatively low population density. The difference in $Q_{F}$ between summer and winter is very small as similar amounts of energy are used to heat buildings in winter as well as cool buildings during summer. Gliwice has the lowest release of $\mathrm{Q}_{\mathrm{F}}$, mainly because the population density is so low.
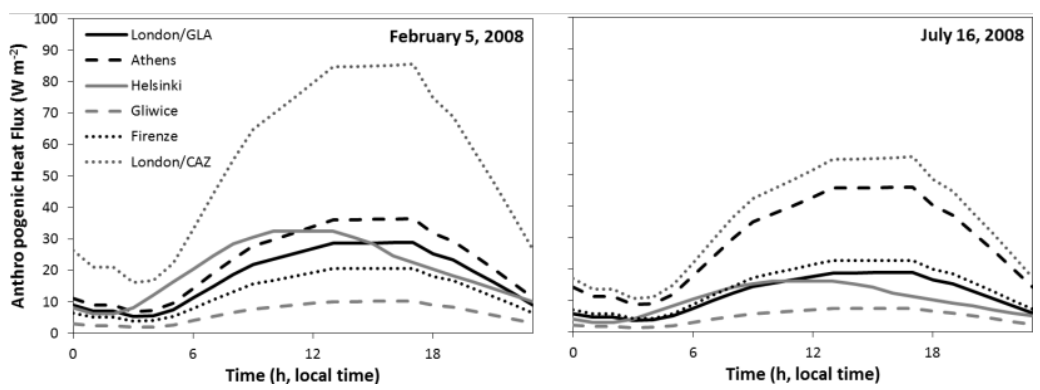

Figure 9.5. Diurnal variations of average anthropogenic heat flux for a winter and summer weekday for then five BRIDGE cities in Europe, 2008.

\section{CONCLUSIONS}

Using the eddy covariance observations (see Chapter 5 for details) collected as part of BRIDGE, it has been possible to test the performance of several urban land surface models to simulate the urban energy balance exchanges. The models used here include models included in in the international urban land surface model comparison (TEB, Noah/SLUCM, LUMPS) and two models that have been developed further within this project (ACASA, SUEWS). 
Grimmond CSB, L Järvi, F Lindberg, S Marras, M Falk, T Loridan, G Pigeon, DR Pyles, D Spano 2015: Urban Energy Budget Models (Chap. 9) in Understanding Urban Metabolism ed N Chrysoulakis, E Castro, E Moors, Routledge, 91-105

http://www.routledge.com/books/details/9780415835114/ ISBN 978-0-415-83511-4

The international urban land surface model comparison concluded that no model had the best overall capability for modelling the surface energy balance fluxes within an urban area (Grimmond et al. 2010, 2011). The results here lead us to similar conclusions. No individual model is best, or worst across the cities in which they were tested for all of the fluxes considered. All of the models have benefited from improvements and additional capabilities added through the BRIDGE project (e.g. Järvi et al. 2011, Loridan et al. 2011, Falk et al.2013, Järvi et al. 2014). This is an important contribution to the evolution of urban land surface modelling.

The model runs demonstrate the importance not only of model physics but also the surface parameters used for the model runs. The need to ensure that these are considered as a whole to understand their relative importance and their suitability for a given site, is critical when land surface modifications are to be considered. If the models are not capable of modelling current conditions and/or responding appropriately to parameters changes, then simulations for future scenarios and different interventions could be very misleading.

Here the SLUCM model is documented to systematically have a problem with the turbulent sensible heat fluxes, notably the ability to transfer heat between sensible and latent heat exchanges. The performance was improved though when appropriate combined model parameters are used (i.e. UZE rather than default WRF values). This has implications that need to be taken into account when modelling surface changes with SLUCM, for example scenarios such as planting trees. Although the ACASA model results are promising, further refinements in the model parameterization are needed to improve the impact of urban surface characteristics on simulated energy fluxes.

\section{REFERENCES}

Allen, L., Lindberg, F. \& Grimmond, C.S.B. (2011). Global to city scale model for anthropogenic heat flux. International Journal of Climatology 31, 1990 - 2005.

American Society of Heating, Refrigeration, and Air Conditioning Engineers (ASHRE) (1992). Report Number 155-1192 Thermal Environment Conditions for Human Occupancy. Atlanta, GA USA.

Bueno, B., Pigeon, G., Norford, L., Zibouche, K. \& Marchadier, C. (2012). Development and evaluation of a building energy model integrated in the TEB scheme. Geoscientific Model Development, 5, 433 - 448.

Chen, F. \& Dudhia, J. (2001). Coupling an advanced land surface-hydrology model with the Penn State-NCAR MM5 modelling system. Part I: Model implementation and sensitivity. Mon. Weather Rev., 129, 569 - 585.

Chen F., Kusaka, H., Bornstein, R., Ching, J., Grimmond, C.S.B., Grossman-Clarke, S., Loridan, T., Manning, K.W., Martilli, A., Miao, S., Sailor, D., Salamanca, F. P., Taha, H., Tewari, M., Wang, X., Wyszogrodzki, A. A. \& Zhang, C. (2011). The integrated WRF/urban modeling system: development, evaluation, \& applications to urban environmental problems, International J. of Climatology, 31, $273-288$.

Chrysoulakis, N., Lopes, M., San José, R., Grimmond, C.S.B., Jones, M.B., Magliulo, V., Klostermann, J.E.M., Synnefa, A., Mitraka, Z., Castro, E., González, A., Vogt, R., Vesala, T., Spano, D., Pigeon, G., Freer-Smith, P., Staszewski, T., Hodges, N., Mills, G., \& Cartalis, C. (2013). Sustainable urban metabolism as a link between bio-physical sciences and urban planning: the BRIDGE project. Landscape and Urban Planning, 112, 100 - 117.

CIESIN, Columbia University; International Food Policy Research Institute (IFPRI), the World Bank; and Centro Internacional de Agricultura Tropical (CIAT) (2004). Global Rural-Urban Mapping Project (GRUMP), Alpha Version: Urban Extents. Palisades, NY: CIESIN, Columbia University. [Online]. Available from: http://sedac.ciesin.columbia.edu/gpw, Accessed July, 30th, 2009.

Falk, M., Pyles, R. D., Marras, S., Spano, D., Paw, K. T. \& Snyder, U, R. L. (2013). Regional simulation of urban metabolism in Helsinki, Finland in 2008. (under review).

Grimmond C.S.B., M. Best, J. Barlow, A.J. Arnfield J.-J. Baik, S. Belcher, M. Bruse, I. Calmet, F. Chen, P. Clark, A. Dandou, E. Erell, K. Fortuniak, R. Hamdi, M. Kanda, T. Kawai, H. Kondo, S. Krayenhoff, S.H. Lee, S.-B. Limor, A. Martilli, V. Masson, S. Miao, G. Mills, R. Moriwaki, K. Oleson, A. Porson, U. Sievers, M. Tombrou, J. Voogt, \& T. Williamson (2009). Urban surface energy balance models: model characteristics \& methodology for a comparison study Urbanization of Meteorological \& Air Quality Models, (eds) Baklanov A, CSB Grimmond, A Mahura, M Athanassiadou Springer-Verlag, ISBN: 978-3-642-00297-7, 97-123.

Grimmond C.S.B., M. Blackett, M. Best, J. Barlow, J.J. Baik, S. Belcher, S.I. Bohnenstengel, I. Calmet, F. Chen, A. Dandou, K. Fortuniak, M.L. Gouvea, R. Hamdi, M. Hendry, T. Kawai, Y. Kawamoto, H. Kondo, E.S. Krayenhoff, S.H. Lee, T. Loridan, A. Martilli, V. Masson, S. Miao, K. Oleson, G. Pigeon, A. Porson, Y.H. Ryu, F. Salamanca, G.J. Steeneveld, M. Tombrou, J. Voogt, D. Young \& N. Zhang (2010). The International Urban Energy Balance Models Comparison Project: First results from Phase 1. J. of Applied Meteorology \& Climatology, 49, 1268-92, doi: 10.1175/2010JAMC2354.1

Grimmond C.S.B., M. Blackett, M.J. Best, J.-J. Baik, S.E. Belcher, J. Beringer, S.I. Bohnenstengel, I. Calmet, F. Chen, A. Coutts, A. Dandou, K. Fortuniak, M.L. Gouvea, R. Hamdi, M. Hendry, M. Kanda, T. Kawai, Y. Kawamoto, H. Kondo, E.S. Krayenhoff, S.-H. Lee, T. Loridan, A. Martilli, V. Masson S. Miao, K. Oleson, R. Ooka, G. Pigeon, A. Porson, Y.-H. Ryu, F. Salamanca, G.-J. Steeneveld, M. Tombrou, J.A. Voogt, D. Young \& N. Zhang (2011). Initial Results from Phase 2 of the International Urban Energy Balance Comparison Project, International J. of Climatology, 31, 244-272 doi: 10.1002/joc.2227

Grimmond C.S.B. \& Oke, T.R. (1991). An evaporation-interception model for urban areas. Water Resources Research, 27,1739 -1755.

Grimmond C.S.B. \& Oke, T.R. (1999). Heat storage in urban areas: observations \& evaluation of a simple model. J. of Applied Meteorology, 38, $922-940$.

Grimmond C.S.B. \& Oke, T.R. (2002). Turbulent heat fluxes in urban areas: Observations \& local-scale urban meteorological parameterization scheme (LUMPS). J. of Applied Meteorology, 41, 792 - 810.

Grimmond C.S.B., Oke, T.R. \& Steyn, D.G. (1986). Urban water balance I: A model for daily totals. Water Resources Research, 22,1397 1403.

Hamdi, R. \& Masson, V. (2008). Inclusion of a drag approach in the town energy balance (TEB) scheme : offline 1-d validation in a street canyon. Journal of Applied Meteorology and Climatology, 47, 2627 - 2644.

ISTAT (2009) http://demo.istat.it/index_e.html. Retrieved 15 September 2013

Janjic, Z.I. (1994). The step-mountain eta coordinate model: further developments of the convection, viscous sublayer and turbulence closure schemes. Mon. Wea. Rev., 122, 927 - 945.

Järvi L, H. Hannuniemi, T. Hussein, H. Junninen, P. P. Aalto, R. Hillamo, T. Mäkelä, P. Keronen, E. Siivola, T. Vesala \& Kulmala, M. (2009). The urban measurement station SMEAR III: Continuous monitoring of air pollution and surface-atmosphere interactions in Helsinki, Finland. Boreal Environ. Res., 14 (Suppl. A), 86 - 109. 
Grimmond CSB, L Järvi, F Lindberg, S Marras, M Falk, T Loridan, G Pigeon, DR Pyles, D Spano 2015: Urban Energy Budget Models (Chap. 9) in Understanding Urban Metabolism ed N Chrysoulakis, E Castro, E Moors, Routledge, 91-105

http://www.routledge.com/books/details/9780415835114/ ISBN 978-0-415-83511-4

Järvi, L., Grimmond, C.S.B. \& Christen, A. (2011). The surface urban energy and water balance scheme (SUEWS): Evaluation in Los Angeles and Vancouver, J. Hydrol. 411, 219 - 237.

Järvi L., Grimmond C.S.B. Taka M., Nordbo A., Setälä H., \& Strachan, I. (2014), Modelling of the energy and water balance in cold climate cities using the Surface Urban Energy and Water balance Scheme (SUEWS), Geosci. Model Dev. Discuss., 7, 1063 - 1114.

Jarvis, P.G. (1976). The interpretation of the variations in leaf water potential and stomatal conductance found in canopies in the field. Philos. Trans. R. Soc. London, Ser. B. 273, 593 - 610.

Kotthaus, S. \& Grimmond, C.S.B. (2013). Energy exchange in a dense urban environment - Part I: temporal variability of long-term observations in central London Urban Climate doi 10.1016/j.uclim.2013.10.002

Kotthaus, S. \& Grimmond, C.S.B. (2012). Identification of Micro-scale Anthropogenic $\mathrm{CO}_{2}$, Heat and Moisture Sources - Processing Eddy Covariance Fluxes for a Dense Urban Environment. Atmospheric Environment 57, 301 - 316.

Kusaka, H. \& Kimura, F. (2004). Thermal effects of urban canyon structure on the nocturnal heat island: Numerical experiment using a mesoscale model coupled with an urban canopy model. J. Appl. Meteorol., 43, 1899 - 1910.

Kusaka H., Kondo H., Kikegawa Y. \& Kimura F. (2001). A simple single layer urban canopy model for atmospheric models: Comparison with multi-layer and slab models. Boundary-Layer Meteorol., 101, 329 - 358.

Lemonsu A., Bélair S., Mailhot J.\& Leroyer S. (2010). Evaluation of the Town Energy Balance model in Cold and Snowy Conditions during the Montreal Urban Snow Experiment 2005. J. of Appl. Meteorol. and Climatol., 49, 346 - 362.

Lemonsu A., Masson V., Shashua-Bar L., Erell E. \& Pearlmutter D. (2012). Inclusion of vegetation in the Town Energy Balance model for modelling urban green areas. Geoscientific Model Development, 5, 1377 - 1393.

Lindberg F., Grimmond C.S.B., Yogeswaran N., Kotthaus S. \& Allen L. (2013). Impact of city changes and weather on anthropogenic heat flux in Europe 1995-2015. Urban Climate, http://dx.doi.org/10.1016/ j.uclim.2013.03.002

Loridan T. \& Grimmond, C.S.B. (2011). Multi-site evaluation of an urban land-surface model: intra-urban heterogeneity, seasonality and parameter complexity requirements. Quarterly Journal of the Royal Meteorological Society, 138, 1094 - 1113.

Loridan T., C.S.B. Grimmond, B.D. Offerle, D.T. Young, T. Smith, L. Järvi \& Lindberg, F. (2011). Local-Scale Urban Meteorological Parameterization Scheme (LUMPS): longwave radiation parameterization \& seasonality related developments. J. of Applied Meteorology \& Climatology, 50, 185 - 202.

Loridan T., F. Lindberg, O. Jorba, S. Kotthaus, S. Grossman-Clarke \& Grimmond C.S.B. (2013). High resolution simulation of surface heat flux variability across central London with Urban Zones for Energy partitioning. Boundary Layer Meteorology, 147, 493 - 523.

Loridan T., Grimmond C.S.B., Offerle B.D., Young D.T., Smith T., Järvi L. \& Lindberg F. (2011). Local-scale urban meteorological parameterization scheme (LUMPS): longwave radiation parameterization and seasonality-related developments. J. Appl. Meteor. Climatol., 50, $185-202$.

Marras, S., R.D. Pyles, M. Falk, M. Casula, R.L. Snyder, K.T. Paw U, \& Spano, D. (2012). Urban fluxes estimation at local and regional scale by ACASA model. ICUC8 - $8^{\text {th }}$ International Conference on Urban Climates, 6th-10th August, 2012, UCD, Dublin, Ireland.

Masson V. (2000). A physically-based scheme for the urban energy budget in atmospheric models. Boundary-Layer Meteorol., 94,357 - 397.

Matese, A., B. Gioli, F. P. Vaccari, A. Zaldei \& Miglietta F. (2009). CO2 emissions of the city center of Firenze, Italy: measurement, evaluation and source partitioning. J. Appl. Meteor. Climatol., 48, $1940-1947$.

Meyers T. P. \& Paw U. K. T. (1986). Testing of a higher-order closure model for modelling airflow within and above plant canopies. BoundLayer Meteor., 31, 297 - 311.

Meyers T. P. \& Paw U. K. T. (1987). Modelling the plant canopy micrometeorology with higher-order closure principles. Agric. For. Meteor., $41,143-163$

Monteith, J.L. (1965). Evaporation and environment. Symp. Soc. Exp. Biol. 19, 205 - 224.

NOAA (2012). ftp://ftp.cmdl.noaa.gov/ccg/co2/trends/co2_annmean_mlo.txt (last access 29/10/2012).

Offerle, B.D., Grimmond, C.S.B. \& Oke, T.R. (2003). Parameterization of net all-wave radiation for urban areas. J. of Applied Meteorology, 42, $1157-1173$.

Parker, D. S., J. E. R. McIlvaine, S. F. Barkaszi, D. J. Beal \& Anello M. T. (2000). Laboratory Testing of the Reflectance Properties of Roofing Material. FSEC-CR-670-00. Florida Solar Energy Center, Cocoa, FL.

Penman, H.L. (1948). Natural evaporation from open water, bare soil and grass. Proc. R. Soc. London, Ser. A. 193, 120 - 145.

Population Register Center of Finland. "VÄESTÖTIETOJÄRJESTELMÄ REKISTERITILANNE 31.8.2013" (in Finnish and Swedish). http://vrk.fi/default.aspx?docid=7675\&site=3\&id=0 (retrieved 15 September 2013).

Pyles, R. D., B. C. Weare, K. T., Paw U., \& Gustafson, W., (2003). Coupling between the University of California, Davis, Advanced CanopyAtmosphere-Soil Algorithm (ACASA) and MM5: Preliminary Results for July 1998 for Western -North America. J Appl. Meteor., 42,557 569.

Vaccari F.P., Gioli B., Toscano P. \& Perrone C. (2013). Carbon dioxide balance assessment of the city of Florence (Italy), and implications for urban planning. Landscape and Urban Planning, 120, 138 - 146.

Vrugt J.A., Gupta H.V., Bastidas L.A., Bouten W. \& Sorooshian S. (2003). Effective and efficient algorithm for multiobjective optimization of hydrological models. Water Resour. Res., 39 (12), 14, DOI:10.1029/2002WR001746

Willmott, C.J., Matsuura, K. \& Legates, D. R. (2009). Terrestrial Air temperature: 1900-2008 Gridded Monthly Time Series (1900-2008) (V. 2.01), [Online]. Available from: http://climate.geog.udel.edu/ climate/ html_pages/download.html\#lw_temp> (accessed 15.01.11). 